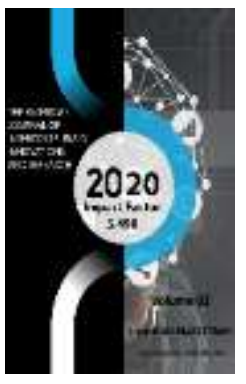

Journal Website: http://usajournalshub.c om/index,php/tajiir

Copyright: Original content from this work may be used under the terms of the creative commons attributes 4.0 licence.

\section{Ways To Improve The Provision Of Trade And Consumer Services In Modern Conditions}

\author{
Usmonova Dilfuza Ilkhomovna, \\ Phd, Associate Professor, Samarkand Institute Of Economics And Service, Samarkand, \\ Uzbekistan
}

Fayziyeva Indira Ilkhomovna, Aspirant, Samarkand Institute Of Economics And Service, Samarkand, Uzbekistan

Usmanov Farzod Shokhrukhovich

Student, Samarkand Institute Of Economics And Service, Samarkand, Uzbekistan

\title{
ABSTRACT
}

This article discusses the principles and approaches to the provision of trade and domestic services in the context of overcoming the economic crisis associated with the coronavirus pandemic. The authors investigated the possibilities of improving the processes of providing services and developing the marketing policy of enterprises in the service sector.

\section{KEYWORDS}

Services, individual services, retail services, domestic services, consumer requirements, standards for the provision of services.

\section{INTRODUCTION}

The socio-economic development of the world economy in modern conditions is characterized by exposure to the influence of many different factors. Globalization processes have made national economies vulnerable to dangers and risks observed in other countries and continents. The spread of coronavirus infection is a good example of this. In just three months, this disease has changed the economic situation around the world, including the Republic of Uzbekistan. 
Over the past three years, Uzbekistan has taken serious steps to overcome the observed negative trends and accelerate the pace of socio-economic development of the country. Cardinal reforms in the field of ensuring the protection of human rights, the inclusion of dialogue mechanisms with neighboring countries on a variety of issues, the conversion of the national currency, the fight against corruption and the development of market mechanisms have significantly improved macroeconomic indicators. In 2019, the country's gross domestic product reached 511838.1 billion soums, that is, the annual growth rate is $5.6 \%$. Such sectors as industry, construction, retail trade made a great contribution to the achievement of high performance.

However, the rapid spread of coronavirus infection has forced the government to take drastic measures to mitigate the negative effects of the pandemic. If in the country the first case of the disease was detected on March 15 of this year, then from March 23, a selfisolation regime was introduced in all large cities, and then in other settlements.

\section{MATERIALS AND METHODS}

The main document that determines state policy during a pandemic is the Decree of the President of the Republic of Uzbekistan Shavkat Mirziyoyev dated March 19, 2020 "On priority measures to mitigate the negative impact on the economy of the coronavirus pandemic and global crisis phenomena." [2] By this decree, the Republican Commission for Combating the Crisis was formed, which determines the boundaries of self-isolation of the population and the procedure for the activities of business entities during the quarantine period. In addition, a program has been adopted to protect business entities from the economic consequences of the selfisolation regime.

Practice shows that self-isolation is the most effective means of preventing the spread of coronavirus infection. At the same time, selfisolation causes enormous damage to the country's economic activity. First of all, the pandemic affected service enterprises and individual entrepreneurs. In addition to traditional service enterprises, all organizations that are focused on customer contacts were forced to suspend their activities.

In pursuance of the decisions of the Commission on the Organization of Economic Activities during the quarantine period, serious changes have occurred in the provision of services. First of all, it is necessary to note the destruction of the existing market situation, that is, in recent months, the volume of traditional types of services has sharply decreased. This is characterized by sanitary and epidemiological requirements, and a decrease in demand for services, and a change in consumer consciousness.

Since the end of April this year, the government has been taking measures to consistently ease the self-isolation regime and restore the economic activity of enterprises and organizations. However, many enterprises were not ready to work in the new conditions. These conditions include adherence to social distance, global disinfection at the entrance to buildings, temperature measurement, testing for the presence of the virus, the use of personal protective equipment. Fulfillment of sanitary requirements is associated not only with additional costs, but also with a change in the usual perception of the process of providing services. 
The service sector is one of the most important spheres of the economy of Uzbekistan. According to the statistics bodies, for the first quarter of 2020, the volume of market services provided amounted to 50365.7 billion soums, which is $9.9 \%$ more than in the same period of 2019. The highest growth rates were shown by financial services, as well as in the field of communications and informatization. In the structure of services rendered, a large place is occupied by transport, financial, trade services (Table 1). [1]

The structure of the rendered services to the Republic of Uzbekistan in January-March and January-May 2020.

\begin{tabular}{|c|c|c|c|c|c|c|c|}
\hline \multirow[t]{2}{*}{ № } & \multirow[t]{2}{*}{ Service list } & \multicolumn{2}{|c|}{$\begin{array}{l}\text { The volume of } \\
\text { services provided, } \\
\text { billion soums }\end{array}$} & \multicolumn{2}{|c|}{ Growth rate, \% } & \multicolumn{2}{|c|}{$\begin{array}{l}\text { Share of types of } \\
\text { services, \% }\end{array}$} \\
\hline & & $\begin{array}{l}\text { January- } \\
\text { March }\end{array}$ & $\begin{array}{l}\text { January- } \\
\text { May }\end{array}$ & $\begin{array}{l}\text { Januar } \\
\text { y- } \\
\text { March }\end{array}$ & $\begin{array}{l}\text { Januar } \\
\text { y-May }\end{array}$ & $\begin{array}{l}\text { January } \\
\text {-March }\end{array}$ & $\begin{array}{l}\text { Januar } \\
\text { y-May }\end{array}$ \\
\hline 1 & $\begin{array}{l}\text { Communication and } \\
\text { informatization } \\
\text { services }\end{array}$ & 2891,9 & 4864,0 & 117,9 & 113,2 & 5,74 & 6,05 \\
\hline 2 & Financial services & 10308,3 & 18057,0 & 136,6 & 131,0 & 20,47 & 22,47 \\
\hline 3 & Transport service & 13335,2 & 19566,6 & 103,1 & 88,3 & 26,47 & 24,35 \\
\hline 4 & $\begin{array}{l}\text { Accommodation and } \\
\text { food services }\end{array}$ & 1391,0 & 2240,5 & 98,2 & 82,0 & 2,76 & 2,79 \\
\hline 5 & Trade services & 12335,5 & 21217,2 & 104,4 & 94,7 & 24,49 & 26,41 \\
\hline 6 & $\begin{array}{l}\text { Services related to real } \\
\text { estate }\end{array}$ & 1527,9 & 2054,3 & 101,8 & 81,7 & 3,03 & 2,56 \\
\hline 7 & Educational services & 2061,4 & 2870,8 & 106,3 & 98,3 & 4,09 & 3,57 \\
\hline 8 & Healthcare services & 787,5 & 1129,0 & 116,2 & 82,0 & 1,56 & 1,41 \\
\hline
\end{tabular}


The American Journal of Interdisciplinary Innovations and Research (ISSN-2642-7478)

Published: October 13, 2020 | Pages: 1-7

\begin{tabular}{|l|l|c|c|c|c|c|c|}
\hline 9 & $\begin{array}{l}\text { Rental and rental } \\
\text { services }\end{array}$ & 1078,0 & 1378,4 & 105,2 & 84,9 & 2,14 & 1,72 \\
\hline 10 & $\begin{array}{l}\text { Services for the repair } \\
\text { of computers and } \\
\text { household goods }\end{array}$ & 805,1 & 1054,2 & 106,0 & 80,8 & 1,6 & 1,31 \\
\hline 11 & Customized services & 1245,8 & 1642,5 & 103,1 & 81,0 & 2,47 & 2,04 \\
\hline 12 & Architectural Services & 921,8 & 1639,8 & 100,8 & 91,1 & 1,83 & 2,04 \\
\hline 13 & Other services & 1676,3 & 2630,7 & 103,3 & 78,1 & 3,33 & 3,28 \\
& & & & & & & 100 \\
\hline
\end{tabular}

According to the above table, it is possible to assess the negative impact of the pandemic on the service sector as a whole and, in particular, for certain types of services. Having studied the growth rates of the volume of services compared to the same period in 2019, we can conclude that a significant decrease in activity was observed in April-May. A particularly large decline is observed in accommodation and food services, health care services, individual services, etc. In addition, there is a change in the structure of services provided by type of activity. For example, an increase in the share of information and communication services, financial services and trade services, was accompanied by a decrease in services directly to the population (services in the field of real estate, education, health care, rent and rental, individual services).

The state is taking all possible measures to compensate for losses to entrepreneurs and to restore their activities as soon as possible. At the same time, one cannot expect that the situation after quarantine will return to its original state. Almost all academic economists in Europe and Asia are unanimous in the opinion that it takes one or two years to overcome the economic consequences of the crisis. We believe that in the service sector even this period is not enough, that is, service sector enterprises need to break existing stereotypes and use new approaches in the provision of services. It should be noted that negative changes did not affect all types of services, that is, in some types of services one can even observe a consumer boom. To investigate problems from a different angle, it is necessary to expand the characteristics of the service classification. In the above table, the classification of services is presented according to their content. However, this classification does not reflect the essence and structure of communications between the seller and the buyer of services. 


\section{RESULT AND DISCUSSION}

As a result of the conducted research, it was revealed that for an objective assessment of the activities of service providers, it is necessary to include an additional classification feature, that is, by the nature of contacts during the provision of services (Table 2). On this basis, services can be grouped into the following groups:

Individual services that require direct contact between the subject and the client in the process of providing services. In this group we would include such types of services as transportation of passengers by public transport, retail trade services, personal services, hotels and catering establishments, all types of education with compulsory attendance of classes, ritual and funeral services, repair and maintenance of equipment for personal use, services with visits to medical institutions, etc .;

Indirect services, that is, services that involve the possibility of their provision using various means of communication without establishing contacts. This group of services includes credit services, payment of payments, government services, transportation of goods, housing services, wholesale trade services, services in the field of housekeeping and agriculture, etc .;

Contactless services, that is, services that do not require direct contact in order to meet the needs of the client. This group includes almost types of communication and informatization services, utilities, most of financial services, exchange trading services, distance education services, design and construction services with a contract construction method, etc.

Table 2

\section{Classification of services in the nature of contact between supplier and customer services}

\begin{tabular}{|l|l|l|}
\hline № & Services list & The nature of the provision of services \\
\hline 1 & Customized services & $\begin{array}{l}\text { The consumer must personally come into contact } \\
\text { with the service provider }\end{array}$ \\
\hline 2 & Indirect services & $\begin{array}{l}\text { The consumer is not obliged to make contact, but } \\
\text { must exchange information in the provision of } \\
\text { services }\end{array}$ \\
\hline 3 & Contactless services & $\begin{array}{l}\text { The consumer and the service provider are not } \\
\text { bound by any obligation of direct or indirect } \\
\text { contact. }\end{array}$ \\
\hline
\end{tabular}

Observations of the activity of enterprises in the service sector during the period of selfisolation showed that the greatest losses were incurred by enterprises providing individual services, including in the field of tourism, consumer services, retail trade and public catering. In the current conditions of easing the self-isolation regime, these enterprises need to develop new principles for organizing their activities and ensuring economic well- 
being. Researches of scientists and practitioners indicate a change in the model of consumer behavior of the population in the field of trade and consumer services.

To comply with sanitary and epidemiological requirements, general recommendations for the activities of personnel at enterprises and organizations have been developed. However, this is not enough for retail and consumer services businesses. It is necessary to use other principles and approaches to organizing the provision of services.

What are the main dangers of the spread of coronavirus infection? This is, first of all, contact with the infected and, secondly, the transmission of infection through objects. Based on this, we propose to use the following principles for organizing shoppers in retail and consumer services:

a. Not to allow the intersection of consumer flows in the service rooms;

b. Limit the time spent by consumers in the service rooms;

c. Ensure the implementation of individual customer service methods and processes;

d. Change the ratio of the useful and total area of enterprises, improve the technological schemes for the planning of places for the provision of services.

It should be borne in mind that sanitary requirements and consumer preferences after the abandonment of the self-isolation regime will remain quite specific and tough.

A study of the experience of mitigating selfisolation in European countries shows that the marketing strategy in retail and consumer services enterprises also requires reflection and improvement. For example, in countries such as Spain, Italy, France, which are focused on international tourism, marketing strategies include not only security, but also high quality service that does not limit the freedom of customers. Likewise, domestic retailers and consumer services must develop completely unique marketing strategies to ensure the attractiveness of their services.

\section{CONCLUSION}

In our opinion, among the priorities in the behavior of consumers of services, the following factors come to the fore:

- Ensuring sanitary safety, that is, attention of the seller of services to the health of the buyer;

- Service rationality. The need for savings during the period of self-isolation forms consumers' assessment of the service in terms of its necessity. Therefore, the service must meet the buyer's usefulness criteria;

- The complexity and availability of the service, that is, the efficiency of the service provided in terms of purchasing costs.

In this case, marketing activities are directed not at the consumer, but at the process of providing services. For example, retailers are required to revise their retail service standards to include provisions such as: information on the number of customers in the sales area, information on when new products arrive, information on the shortest paths to individual products, service speed during the selection period, and mutual settlements, organization of delivery of purchases to transport, etc.

The specifications for the provision of individual services by consumer service establishments also need to be improved. As you know, the process of providing individual consumer services involves a queue of customers. For normal activities after a coronavirus pandemic, it is necessary to 
eliminate queues or distribute them in space and time. To do this, in the service process, it is necessary to include the reception of the client at a predetermined time, the organization of recreational areas or separate premises, customer service at home and other forms of service deliver.

\section{REFERENCES}

1. Official website of the State Committee of the Republic of Uzbekistan on Statistics. Press releases. www.stat.uz

2. Decree of the President of the Republic of Uzbekistan Shavkat Mirziyoyev UP-5969 dated March 19, 2020 "On priority measures to mitigate the negative impact on the economic sectors of the coronavirus pandemic and global crisis phenomena." Electronic resource. www.lex.uz

3. 5 Things Advertisers Should Consider Amidst the COVID-19 Pandemic. Electronic resource.

https://www.entrepreneur.com/article/34 8526 